NISTIR 89-3908

\title{
INTERLABORATORY COMPARISON OF TWO TYPES OF LINE-SOURCE THERMAL-CONDUCTIVITY APPARATUS MEASURING FIVE INSULATING MATERIALS
}

Jerome G. Hust

David R. Smith

National Institute of Standards and Technology (formerly National Bureau of Standards)

U.S. Department of Commerce

Boulder, Colorado 80303-3328

January 1989 



\section{INTERLABORATORY COMPARISON OF TWO TYPES OF LINE-SOURCE THERMAL-CONDUCTIVITY APPARATUS MEASURING FIVE INSULATING MATERIALS}

Jerome G. Hust

David R. Smith

Chemical Engineering Science Division

Center for Chemical Engineering

National Engineering Laboratory

National Institute of Standards and Technology

Boulder, Colorado 80303-3328

January 1989

Sponsored, in part, by

U.S. Department of Energy

Oak Ridge National Laboratory

Oak Ridge, Tennessee 37830

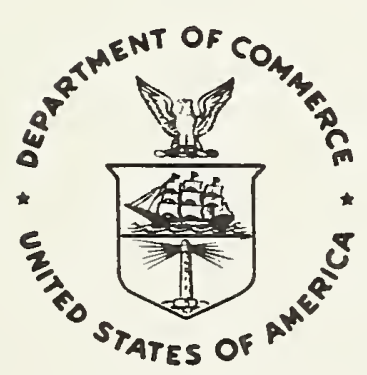

U.S. DEPARTMENT OF COMMERCE, C. William Verity, Secretary

Ernest Ambler, Acting Under Secretary for Tech.nology

NATIONAL INSTITUTE OF STANDARDS AND TECHNOLOGY, Raymond G. Kammer, Acting Director 

CONTENTS

Page

LIST OF TABLES. ...................... iv

LIST OF FIGURES. . . . . . . . . . . . . . . . .

ABSTRACT $\ldots \ldots \ldots \ldots \ldots \ldots \ldots \ldots \ldots \ldots \ldots \ldots \ldots \ldots \ldots \ldots \ldots \ldots \ldots$

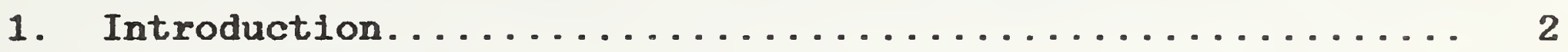

2. Scope................................ 2

3. Experimental Data........................ 3

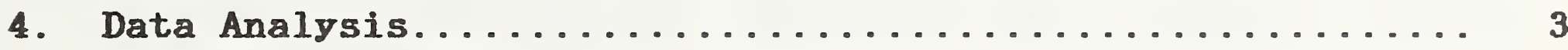

5. Summary and Conclusions...................... 4

6. References........................... 4 
Table 1. Dimensions and Densities of Specimpns Used in the

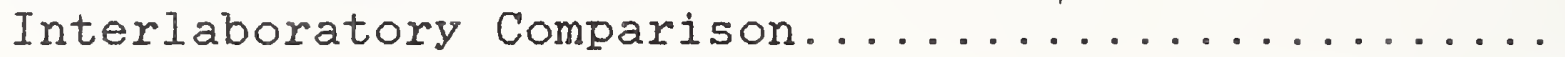

Table 2. Laboratory Codes and Features of Apparatus......... 5

Table 3. Thermal Conductivity of the Fibrous Glass Specimens..

Table 4. Thermal Conductivity of the Expanded Folystyrene

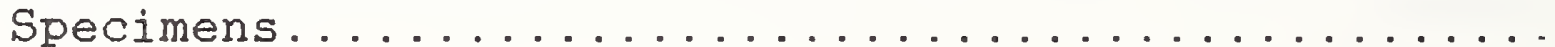

Table 5. Thermal Conductivity of the Extruded Polystyrene

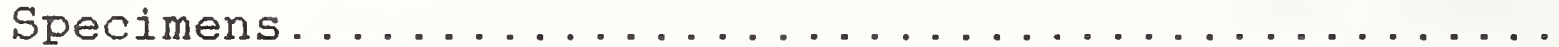

Table 6. Thermal Conductivity of the Ottawa Silica Sand

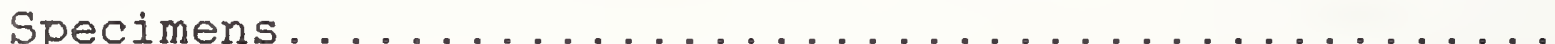

Table 7. Thermal Conductivity for the Paraffin Wax Specimens.. 10

Table 8. Mean Thermal Conductivity and Percent Standard Deviation from the Mean for Each Type of Apparatus and Each Material...................... 11 
Figure 1. Interlaboratory comparison of thermal conductivity of fibrous glass insulation with a density of 45 $\mathrm{kg} / \mathrm{m}^{3}$. The solid line indicates the trend of data rom the literature on similar material....

Figure 2. Interlaboratory comparison of thermal conductivity of expanded polystyrene insulation with a density of $21 \mathrm{~kg} / \mathrm{m}^{3}$. The solid line indicates the trend of data from the literature on similar

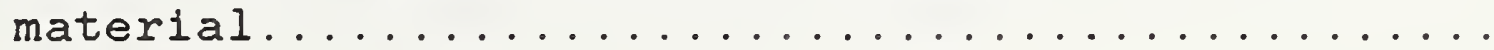

Figure 3. Interlaboratory comparison of thermal conductivity of extruded polystyrene insulation with a density of $32 \mathrm{~kg} / \mathrm{m}^{3}$. The solid line indicates the trend of data from the literature on similar

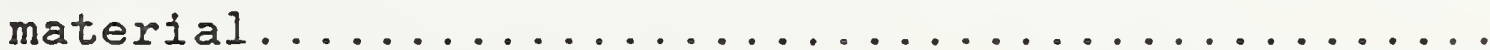

Figure 4. Interlaboratory comparison of thermal conductivity of paraffin wax with a density of $850 \mathrm{~kg} / \mathrm{m}^{3}$. The solid line indicates the trend of data from the

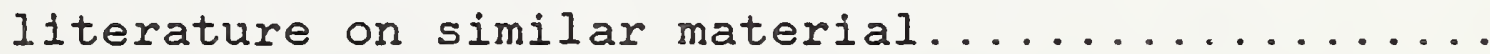

Figure 5. Interlaboratory comparison of thermal conductivity of Ottawa silica sand with a density of 1640 $\mathrm{kg} / \mathrm{m}^{3}$. Downward-pointing triangles represent data for sand containing 3.5 percent by weight of moisture; all other symbols are for dry

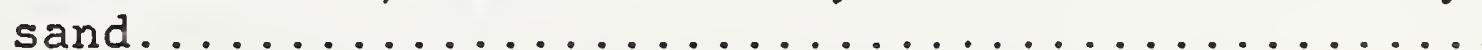

Figure 6. Interlaboratory comparison of thermal conductivity of dry Ottawa silica sand with a density of $1640 \mathrm{~kg} / \mathrm{m}^{3}$. The solid line indicates the trend of data from the literature on similar material........................ 17

Figure 7. Interlaboratory comparison of thermal conductivity of Ottawa silica sand with a density of 1640 $\mathrm{kg} / \mathrm{m}^{3}$ and containing 3.5 percent by weight of

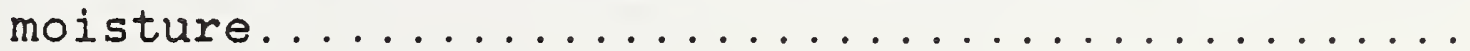



Interlaboratory Comparison of Two Types of Line-Source Thermal-

Conductivity Apparatus Measuring Five Insulating Materials

\author{
Jerome G. Hust \\ David R. Smith \\ Center for Chemical Engineering \\ National Engineering Laboratory \\ National Institute of Standards and Technology \\ Boulder, CO 80303-3328
}

We compare measurements of apparent thermal conductivity performed by five different laboratories. Subcommittee C-16.30 (Thermal Measurements) of the American Society for Testing and Materials (ASTM) sponsored this interlaboratory comparison. Two different types of line-source apparatus were used: the needle and the hot wire. The five laboratories measured thermal conductivity of Ottawa silica sand, paraffin wax, and three insulating materials (fibrous glass, expanded polystyrene, and extruded polystyrene). Comparison of the test results illustrates the interlaboratory reproducibility. The standard deviation of the thermal conductivity results for the needle apparatus is 26 percent, whereas the standard deviation of the results for the hot-wire apparatus is 17 percent. For the insulating materials the mean values of the test results from the needle apparatus lie about 35 percent below those for the hot-wire apparatus. For the more dense materials, Ottawa sand and paraffin wax, the difference is about 15 percent. We do not at present know which apparatus is the more accurate. Further work needs to be done to establish and/or improve the reliability of each of these methods for use in a laboratory environment such as for quality control or research.

Key words: ambient temperature; apparent thermal conductivity; expanded polystyrene; extruded polystyrene; fibrous glass; hot wire; irterlaboratory comparison; line-source apparatus; needle probe; Ottawa silica sand; paraffin wax; thermal insulation.

Th1s work was funded, in part, by DOE/ORNL under contract ORNL/IA21428. 


\section{Introduction}

During the last two decades equipment and techniques for measuring thermal resistance of thermal insulations have been appreciably improved, particularly for measurements at ambient temperature. There is considerable interest in using apparatus that measure thermal conductivity more rapidly than can steady-state apparatus such as the guarded hot plate and heat flow meter. Rapid measurements are especially important for production-line analysis. Transient measurement techniques, such as the needle probe and the hot wire, are attractive from the standpoint of speed.

However, little is known about the precision and bias of these transient methods. As a consequence, a committee was formed under the auspices of Subcommittee C-16.30 of the American Society of Testing and Materials to perform an interlaboratory comparison (ILC) using Iine-source apparatus at ambient temperatures. The ILC was initiated in 1985 under the direction of Mark Bomberg of the National Research Council (NRC) of Canada. He prepared most of the specimens for distribution to the participants. However, due to a change in his duties, the direction of the task was transferred to the first author, at the Boulder, Colorado Laboratory of the National institute of Standards and Technology (NIST), formerly the National Bureau of Standards (NBS). The available specimens were transferred from NRC to NIST-Boulder, which characterized and distributed them to the participarts.

\section{Scope}

This report presents and analyzes thermal conductivity data obtained in the ILC for five different materials. Frior to shipping the specimens to the participants, the densities were measured at NIST-B. The specimens are characterized ir table 1. The densities of the specimens of paraffin wax and Ottawa silica sand could not be determined at NIST because these specimens were prepared in place by the participants. In addition, only two specimens of sard, and four of paraffin wax, were distributed. These specimens were sent from one participant to another for testing.

The rames of the six testing laboratories participating in the ILC are given here to idertify the sources of the data presented. Listing the rames of the five commercial firms does not in any way imply endorsement of the companies or of their products by the National Institute of Standards and Technology or by the U.S. goverrment. The participants were:

Dynatech R/D Company (now Holometrix, Inc.), Cambridge, Mass. Geotherm Inc., Newmarket, Ontario, CANADA

Manville Corporation, Denver, Colo.

National Refractories and Minerals, Pleasanton, Cal. 
Ontario Hydro, Toronto, Ontario, CANADA

U.S. National Institute of Standards and Technology (NIST), (formerly National Bureau of Standards), Boulder, Colo.

Random numbers and symbols were assigned to the data sets from these laboratories for use throughout this report. These laboratory codes are given in table 2. Also given in table 2 are some of the salient features, where known, of the apparatus used by each participant. Some laboratories did not report the lengths or diameters of their hot wires or needle probes.

\section{Experimental Data}

We compiled the experimental data for thermal conductivity of the different materials into tabular files for analysis by computer. Tables 3 through 7 contain the raw data as supplied by the five participants in the ILC and converted by the authors to sI units.

\section{Data Analysis}

Thermal conductivity test results for each of the five materials are shown in figures 1 through 7. Due to the large scatter in the data, no functional dependence of thermal conductivity on temperature is deducible. Table 8 lists the mean value of thermal conductivity and the standard deviation from the mean, for each material and for both types of apparatus.

Thermal conductivity test results on the insulating materials (fibrous glass; expanded and extruded polystyrene) all exhibit the same trend (figs. 1-3). For these materials the mean values from the needle apparatus all lie about $35 \%$ below those of the hot-wire apparatus. For the paraffin wax and cttawa sand the results for the needle device are also appreciably different from those of the hot-wire apparatus (figs. 4-6).

Each solid line in figures 1-4 and figure 6 is an estimate of the thermal conductivity of the corresponding material, obtained from a Iimited examination of literature data for similar materials. Uncertainties in moisture content and density for the literature material, and for each material as measured by the participarts, preclude matching literature data exactly with the data for the particular specimens used here. However, the slopes of the solid Iines suggest trends of thermal conductivity with temperature that are helpful in comparing the results. Different mear values of conductivity for each laboratory may be due to uncorrected biases, but if the biases are insersitive to temperature over the range studied, correct slopes might still be obtained. Even these slopes cannot be deduced here due to the scatter in the data collection taken as a whole. The slope of conductivity with temperature for some individual laboratories is consistent with that suggested by the solid line. 
Figure 4 shows the results for paraffin wax. Again there is a clear difference between the results from the needle probe and those from the hot-wire apparatus, with data from the needle probe generally lying 7 percent higher than those from the hot wire (Table 8).

Figure 5 shows the results for Ottawa silica sand. This composite plot contains data for both dry sand and sand containing 3.5 percent by weight of moisture (downward-pointing triangles). Figures 6 and 7 show these data separately. The moist sand shows a significantly greater apparent thermal conductivity. This is not surprising, for moisture, as a condensed phase, would be expected to contribute its thermal conductivity to that of the sand grains. Moisture would bridge across between sharp points and edges of adjoining grains, greatly reducing the inter-grain contact resistance. For a transient measurement method, represented here by both the reedle and the hot wire, moisture migration would contribute heat transfer along with the mass transfer. The mean values of the test results from the needle apparatus are 14 percent lower than values obtained with the hot-wire apparatus.

\section{Summary and Conclusions}

With the exception of the results for paraffin wax, thermal conductivity test results measured in this ILC with the needle probe lie 14 to 35 percent lower than the results with the hot wire. This large difference in results from the two apparatus casts doubt on the accuracy of measurements performed on either apparatus. At present there are no measurements that would permit the establishment of the accuracy of either apparatus by direct comparison with results from guarded hot plates or from heat-flow meters. Furthermore, these results are considerably more scattered than those obtained from steady-state methods as recently reported [1]. Thus it is debatable whether either apparatus is suitable even for use in comparative measurements, such as might be used in quality control. It is not now clear what the principal source of the scatter is. Further work needs to be done to establish and/or improve the reliability of each of these methods for use in a laboratory environment such as quality control or research.

\section{References}

1. Hust, J.G. and Pelanne, C.M., "Round robins on the apparent thermal conductivity of low-density glass fiber insulations using guarded hot plate and heat flow meter apparatus", NBSIR 85-3026, U.S. National Institute of Standards and Technology, 1985. 
Table 1. Dimensions and Densities of Specimens Used in the Interlaboratory Comparison.

\begin{tabular}{|c|c|c|c|c|c|c|}
\hline------- & -------- & $\begin{array}{l}\text { Length } \\
(\mathrm{cm})\end{array}$ & $\begin{array}{l}\text { Thickness } \\
(\mathrm{cm})\end{array}$ & $\begin{array}{l}\text { Width } \\
(\mathrm{cm})\end{array}$ & $\begin{array}{l}\text { Mass } \\
(\mathrm{g}) \\
------\end{array}$ & $\begin{array}{l}\text { Density } \\
\left(\mathrm{kg} / \mathrm{m}^{3}\right)\end{array}$ \\
\hline $\begin{array}{c}\text { Fibrous } \\
\text { glass: }\end{array}$ & $\begin{array}{l}\text { Fib (1) } \\
\text { Fib (4) } \\
\text { Fib (5) } \\
\text { Fib (6) } \\
\text { Fib }(7)\end{array}$ & $\begin{array}{l}61.00 \\
61.00 \\
60.90 \\
60.70 \\
60.70\end{array}$ & $\begin{array}{l}12.70 \\
12.67 \\
12.67 \\
12.50 \\
12.45\end{array}$ & $\begin{array}{l}11.73 \\
11.81 \\
11.76 \\
11.66 \\
11.68\end{array}$ & $\begin{array}{l}402.90 \\
424.00 \\
425.40 \\
405.10 \\
422.90\end{array}$ & $\begin{array}{l}44.34 \\
46.45 \\
46.88 \\
45.79 \\
47.91\end{array}$ \\
\hline $\begin{array}{l}\text { Expanded } \\
\text { Poly- } \\
\text { styrene: }\end{array}$ & $\begin{array}{l}\operatorname{Exp}(1) \\
\operatorname{Exp}(4) \\
\operatorname{Exp}(5) \\
\operatorname{Exp}(6) \\
\operatorname{Exp}(7)\end{array}$ & $\begin{array}{l}59.90 \\
59.60 \\
59.80 \\
59.80 \\
59.70\end{array}$ & $\begin{array}{l}9.47 \\
9.40 \\
9.40 \\
9.40 \\
9.37\end{array}$ & $\begin{array}{l}17.68 \\
17.73 \\
17.73 \\
17.70 \\
17.73\end{array}$ & $\begin{array}{l}216.10 \\
200.30 \\
206.00 \\
209.60 \\
208.30\end{array}$ & $\begin{array}{l}21.55 \\
20.16 \\
20.67 \\
21.07 \\
21.00\end{array}$ \\
\hline $\begin{array}{l}\text { Extruded } \\
\text { Poly- } \\
\text { styrene: }\end{array}$ & $\begin{array}{l}\text { Ext (1) } \\
\text { Ext (4) } \\
\text { Ext (5) } \\
\text { Ext (6) } \\
\text { Ext (7) }\end{array}$ & $\begin{array}{l}60.90 \\
61.00 \\
60.90 \\
61.20 \\
60.90\end{array}$ & $\begin{array}{r}10.11 \\
9.98 \\
10.01 \\
10.03 \\
10.11\end{array}$ & $\begin{array}{l}17.75 \\
17.70 \\
17.78 \\
17.68 \\
17.75\end{array}$ & $\begin{array}{l}346.70 \\
360.70 \\
361.30 \\
360.50 \\
360.50\end{array}$ & $\begin{array}{l}31.72 \\
33.47 \\
33.33 \\
33.22 \\
32.99\end{array}$ \\
\hline Paraffin: & $\begin{array}{l}\operatorname{FWX}(1) \\
\operatorname{PWX}(3) \\
\operatorname{PWX}(4)\end{array}$ & & & & & $\begin{array}{l}830, \quad 890 \\
900 .\end{array}$ \\
\hline $\begin{array}{l}\text { Ottawa } \\
\text { silica } \\
\text { sand: }\end{array}$ & $\begin{array}{l}\text { OSS (1) } \\
\text { OSS (2) }\end{array}$ & & & & & $\begin{array}{l}1640 . \\
1640 .\end{array}$ \\
\hline
\end{tabular}

Table 2. Laboratory Codes and Features of Apparatus.

\begin{tabular}{|c|c|c|c|c|}
\hline $\begin{array}{l}\text { Lab. } \\
\text { No. }\end{array}$ & $\begin{array}{l}\text { Apparatus } \\
\text { Type }\end{array}$ & $\begin{array}{l}\text { Active } \\
\text { Length } \\
\text { (cm) }\end{array}$ & $\begin{array}{c}\text { Diameter } \\
(\mathrm{mm})\end{array}$ & $\begin{array}{l}\text { Symbols used } \\
\text { in Figures }\end{array}$ \\
\hline $\begin{array}{l}1 \\
2 \\
3 \\
4 \\
5\end{array}$ & $\begin{array}{c}\text { Needle } \\
\text { Wire } \\
\text { Wire } \\
\text { Needle } \\
\text { Wire }\end{array}$ & $\begin{array}{l}10 \\
15 \\
20 \\
15 \\
\text { NR }\end{array}$ & $\begin{array}{l}3.2 \\
0.37 \\
\text { NR* } \\
3 \\
\text { NR }\end{array}$ & $\begin{array}{l}0 \\
\Delta \\
\square \\
\nabla \\
\Delta\end{array}$ \\
\hline
\end{tabular}


Table 3. Thermal Conductivity of the Fibrous Glass Specimens

\begin{tabular}{|c|c|c|c|c|c|}
\hline $\begin{array}{l}\text { Lab } \\
\text { Code }\end{array}$ & $\begin{array}{l}\text { Specimen } \\
\text { Identifier }\end{array}$ & $\begin{array}{c}\text { Test } \\
\text { Durotion } \\
(8)\end{array}$ & $\begin{array}{l}\text { Temp. } \\
\text { Rise } \\
(K)\end{array}$ & $\begin{array}{l}\text { Mean } \\
\text { Temp. } \\
(K)\end{array}$ & $\begin{array}{c}\text { Thermal } \\
\text { Conductivity } \\
\mathrm{mw} /(\mathrm{m} . \mathrm{k})\end{array}$ \\
\hline 1 & $F I B(5)$ & 600 & 6.00 & 295.00 & 24.00 \\
\hline 1 & $F I B(5)$ & 600 & 3.00 & 295.00 & 24.00 \\
\hline 1 & $F I B(5)$ & 600 & 2.20 & 296.50 & 22.00 \\
\hline 1 & $F I B(5)$ & 600 & 8.50 & 295.00 & 22.00 \\
\hline 2 & $F I B(1)$ & 564 & 1.55 & 298.06 & 36.40 \\
\hline 2 & $\operatorname{FIB}(1)$ & 564 & 4.66 & 301.12 & 37.00 \\
\hline 2 & $F I B(1)$ & 564 & 10.16 & 306.45 & 37.40 \\
\hline 3 & F IB (7) & NR & 20.00 & 305.15 & 33.80 \\
\hline 3 & $F I B(7)$ & NR & 20.00 & 307.15 & 35.00 \\
\hline 3 & FIB (7) & NR & 20.00 & 307.15 & 34.30 \\
\hline 3 & $\operatorname{FIB}(7)$ & NR & 20.00 & 308.15 & 34.80 \\
\hline 3 & $\operatorname{FIB}(7)$ & NR & 20.00 & 307.15 & 34.70 \\
\hline 3 & $F \operatorname{IB}(7)$ & NR & 20.00 & 308.15 & 35.50 \\
\hline 3 & $\operatorname{FIB}(7)$ & NR & 20.00 & 308.15 & 34.30 \\
\hline 3 & FIB (7) & NR & 20.00 & 308.15 & 33.30 \\
\hline 3 & $F I B(7)$ & NR & 20.00 & 308.15 & 34.00 \\
\hline 3 & $F I B(7)$ & NR & 20.00 & 308.15 & 34.90 \\
\hline 3 & $F I B(7)$ & NR & 39.00 & 317.15 & 37.00 \\
\hline 3 & $F I B(7)$ & $\mathrm{Nk}$ & 39.00 & 317.15 & 36.80 \\
\hline 4 & $F I B(6)$ & 600 & 2.27 & 300.54 & 23.00 \\
\hline 4 & $F I B(6)$ & 600 & 2.37 & 300.20 & 21.00 \\
\hline 4 & $F I B(6)$ & 600 & 4.89 & 301.58 & 18.00 \\
\hline 4 & $F I B(6)$ & 1200 & -3.34 & 300.01 & 21.00 \\
\hline 4 & $\operatorname{FIB}(6)$ & 1200 & -3.42 & 299.67 & 21.00 \\
\hline 4 & $F I B(6)$ & 1200 & 6.22 & 300.91 & 28.00 \\
\hline 5 & F IB (4) & NR & NR & 295.95 & 35.00 \\
\hline 5 & $\operatorname{FIB}(4)$ & NR & NR & 295.95 & 36.20 \\
\hline 5 & $\operatorname{FIB}(4)$ & NR & NR & 297.35 & 37.00 \\
\hline
\end{tabular}


Toble 4. Thermal Conductivity of the Exponded Polystyrene Specimens.

\begin{tabular}{|c|c|c|c|c|c|}
\hline $\begin{array}{l}\text { Lob } \\
\text { Code }\end{array}$ & $\begin{array}{l}\text { Specimen } \\
\text { Identifier }\end{array}$ & $\begin{array}{c}\text { Test } \\
\text { Duration } \\
(\mathrm{s})\end{array}$ & $\begin{array}{l}\text { Tomp. } \\
\text { Rise } \\
\text { (K) }\end{array}$ & $\begin{array}{l}\text { Mean } \\
\text { Temp. } \\
\text { (K) }\end{array}$ & $\begin{array}{l}\text { Thermal } \\
\text { Conduct ivity } \\
m W /(m . K)\end{array}$ \\
\hline 1 & $\operatorname{EXP}(5)$ & 600 & 7.00 & 295.00 & 21.80 \\
\hline 1 & $\operatorname{EXP}(5)$ & 606 & 3.00 & 295.00 & 20.00 \\
\hline 1 & $\operatorname{EXP}(5)$ & 600 & 2.30 & 296.50 & 22.00 \\
\hline 1 & $\operatorname{EXP}(5)$ & 600 & 8.70 & 295.00 & 22.00 \\
\hline 2 & $\operatorname{EXP}(1)$ & 564 & 1.48 & 296.93 & 32.40 \\
\hline 2 & $\operatorname{Exp}(1)$ & 564 & 5.02 & 299.86 & 33.00 \\
\hline 2 & $\operatorname{EXP}(1)$ & 564 & 10.82 & 305.17 & 33.40 \\
\hline 3 & $\operatorname{EXP}(7)$ & NR & 20.00 & 307.15 & 31.00 \\
\hline 3 & $\operatorname{EXP}(7)$ & NR & 20.00 & 307.15 & 29.70 \\
\hline 3 & $\operatorname{EXP}(7)$ & NR & 20.00 & 308.15 & 30.50 \\
\hline 3 & $\operatorname{EXP}(7)$ & NR & 20.00 & 309.15 & 30.90 \\
\hline 3 & $\operatorname{EXP}(7)$ & NR & 20.00 & 308.15 & 30.80 \\
\hline 3 & $\operatorname{EXP}(7)$ & NR & 20.00 & 306.15 & 29.70 \\
\hline 3 & $\operatorname{EXP}(7)$ & NR & 20.80 & 308.15 & 30.10 \\
\hline 3 & $\operatorname{EXP}(7)$ & NR & 20.00 & 308.15 & 29.30 \\
\hline 3 & $\operatorname{EXP}(7)$ & NR & 20.00 & 308.15 & 29.10 \\
\hline 3 & $\operatorname{EXP}(7)$ & NR & 20.00 & 308.15 & 29.10 \\
\hline 3 & $\operatorname{EXP}(7)$ & NR & 20.00 & 308.15 & 29.40 \\
\hline 3 & $\operatorname{EXP}(7)$ & NR & 20.00 & 309.15 & 29.50 \\
\hline 3 & $\operatorname{EXP}(7)$ & NR & 20.00 & 308.15 & 29.70 \\
\hline 3 & $\operatorname{EXP}(7)$ & NR & 38.00 & 317.15 & 31.10 \\
\hline 3 & $\operatorname{EXP}(7)$ & NR & 38.00 & 319.15 & 31.50 \\
\hline 4 & $\operatorname{EXP}(6)$ & 600 & 5.91 & 301.45 & 15.00 \\
\hline 4 & $\operatorname{EXP}(6)$ & 600 & 2.46 & 300.67 & 21.00 \\
\hline 4 & $\operatorname{EXP}(6)$ & 1200 & -6.66 & 301.07 & 17.00 \\
\hline 4 & $\operatorname{EXP}(6)$ & 1200 & -3.77 & 300.02 & 28.75 \\
\hline 5 & $\operatorname{EXP}(4)$ & NR & NR & 296.05 & 33.58 \\
\hline 5 & $\operatorname{EXP}(4)$ & NR & NR & 295.85 & 31.56 \\
\hline 5 & $\operatorname{EXP}(4)$ & NR & NR & 295.75 & 32.42 \\
\hline
\end{tabular}


Table 5. Thermal Conductivity of the Extruded Polystyrene Specimens.

\begin{tabular}{|c|c|c|c|c|c|}
\hline $\begin{array}{l}\text { Lab } \\
\text { Code }\end{array}$ & $\begin{array}{l}\text { Specimen } \\
\text { Ident ifier }\end{array}$ & $\begin{array}{c}\text { Tost } \\
\text { Duration } \\
\text { (s) }\end{array}$ & $\begin{array}{l}\text { Temp. } \\
\text { Rise } \\
\text { (K) }\end{array}$ & $\begin{array}{l}\text { Meon } \\
\text { Temp. } \\
\text { (K) }\end{array}$ & $\begin{array}{l}\text { Thermal } \\
\text { Conductivity } \\
\text { mW/(m.K) }\end{array}$ \\
\hline 1 & $\operatorname{EXT}(5)$ & 600 & 7.00 & 295.00 & 19.00 \\
\hline 1 & EXT(5) & 600 & 4.00 & 295.00 & 18.00 \\
\hline 1 & EXT(5) & 600 & 2.30 & 296.50 & 20.00 \\
\hline 1 & EXT(5) & 600 & 8.90 & 295.00 & 21.00 \\
\hline 2 & EXT(1) & 564 & 1.58 & $297: 50$ & 29.70 \\
\hline 2 & EXT(1) & 564 & 5.43 & 300.82 & 28.60 \\
\hline 2 & $\operatorname{EXT}(1)$ & 564 & 11.41 & 306.07 & 29.00 \\
\hline 3 & EXT(7) & NR & 20.00 & 306.15 & 28.40 \\
\hline 3 & EXT(7) & NR & 20.00 & 307.15 & 29.20 \\
\hline 3 & $\operatorname{EXT}(7)$ & NR & 20.00 & 308.15 & 29.50 \\
\hline 3 & $\operatorname{EXT}(7)$ & NR & 20.00 & 308.15 & 28.10 \\
\hline 3 & $\operatorname{EXT}(7)$ & NR & 20.00 & 306.15 & 28.00 \\
\hline 3 & EXT(7) & NR & 20.00 & 308.15 & 29.70 \\
\hline 3 & $\operatorname{EXT}(7)$ & NR & 20.00 & 308.15 & 28.60 \\
\hline 3 & $\operatorname{EXT}(7)$ & NR & 20.00 & 308.15 & 27.50 \\
\hline 3 & $\operatorname{EXT}(7)$ & NR & 20.00 & 308.15 & 30.10 \\
\hline 3 & $\operatorname{EXT}(7)$ & NR & 20.00 & 308.15 & 29.30 \\
\hline 3 & EXT(7) & NR & 20.00 & 308.15 & 28.00 \\
\hline 3 & $\operatorname{EXT}(7)$ & NR & 37.50 & 317.15 & 29.90 \\
\hline 3 & $\operatorname{EXT}(7)$ & NR & 37.50 & 318.15 & 29.90 \\
\hline 4 & EXT(6) & 600 & 5.64 & 303.26 & 17.00 \\
\hline 4 & EXT(6) & 600 & 2.70 & 300.72 & 19.00 \\
\hline 4 & $\operatorname{EXT}(6)$ & 1200 & -7.34 & 302.41 & 16.00 \\
\hline 4 & $\operatorname{EXT(6)}$ & 1200 & -3.74 & 300.20 & 18.00 \\
\hline 5 & $\operatorname{EXT}(4)$ & NR & NR & 295.75 & 26.08 \\
\hline 5 & $\operatorname{EXT}(4)$ & NR & NR & 295.65 & 27.38 \\
\hline 5 & $\operatorname{EXT}(4)$ & NR & NR & 296.25 & 26.80 \\
\hline
\end{tabular}


Table 6. Thermal Conductivity of the Ottawa Silica Sand Specimens.

\begin{tabular}{|c|c|c|c|c|c|}
\hline $\begin{array}{l}\text { Lob } \\
\text { Code }\end{array}$ & $\begin{array}{l}\text { Specimen } \\
\text { Identifior }\end{array}$ & $\begin{array}{c}\text { Test } \\
\text { Duration } \\
\text { (s) }\end{array}$ & $\begin{array}{l}\text { Temp. } \\
\text { Rise } \\
(K)\end{array}$ & $\begin{array}{l}\text { Mean } \\
\text { Temp. } \\
(K)\end{array}$ & $\begin{array}{l}\text { Thermal } \\
\text { Conductivity } \\
\mathrm{mw} /(\mathrm{m} \cdot \mathrm{K})\end{array}$ \\
\hline 1 & $\operatorname{oss}(1)$ & 600 & 7.00 & 295.00 & 287.00 \\
\hline 1 & $\operatorname{oss}(1)$ & 600 & 4.00 & 295.00 & 288.00 \\
\hline 1 & $\operatorname{oss}(1)$ & 600 & 2.50 & 295.00 & 268.00 \\
\hline 1 & oss (1) & 600 & 7.30 & 295.00 & 289.00 \\
\hline 2 & $\operatorname{oss}(2)$ & 564 & 0.61 & 300.14 & 365.80 \\
\hline 2 & $\operatorname{oss}(2)$ & 564 & 5.91 & 305.62 & 371.00 \\
\hline 2 & $\operatorname{oss}(2)$ & 564 & 16.84 & 316.15 & 349.40 \\
\hline 3 & $\operatorname{oss}(2)$ & NR & 20.00 & 309.15 & 269.00 \\
\hline 3 & $\operatorname{oss}(2)$ & NR & 20.00 & 308.15 & 288.00 \\
\hline 3 & $\operatorname{oss}(2)$ & NR & 20.00 & 308.15 & 293.00 \\
\hline 3 & $\operatorname{oss}(2)$ & NR & 20.00 & 309.15 & 300.00 \\
\hline 3 & $\operatorname{oss}(2)$ & NR & 20.00 & 310.15 & 288.00 \\
\hline 3 & $\operatorname{oss}(2)$ & NR & 20.00 & 312.15 & 291.00 \\
\hline 3 & $\operatorname{oss}(2)$ & NR & 20.00 & 310.15 & 278.00 \\
\hline 4 & $\operatorname{Oss}(1-\theta)$ & 600 & 0.40 & 298.22 & 291.00 \\
\hline 4 & $\operatorname{coss}(1-\theta)$ & 600 & 6.51 & 314.23 & 294.00 \\
\hline 4 & $\operatorname{oss}(1-\theta)$ & 600 & 4.09 & 308.04 & 287.00 \\
\hline 4 & $\operatorname{coss}(1-\theta)$ & 1200 & -1.08 & 297.88 & 232.00 \\
\hline 4 & $\operatorname{coss}(1-0)$ & 1200 & -18.20 & 308.38 & 216.00 \\
\hline 4 & $\operatorname{coss}(1-\theta)$ & 1200 & -11.46 & 304.35 & 216.00 \\
\hline 4 & $\operatorname{coss}(1-3.5)$ & 600 & 0.08 & 298.08 & 1194.00 \\
\hline 4 & $\operatorname{coss}(1-3.5)$ & 600 & 0.44 & 299.40 & 1819.00 \\
\hline 4 & $\operatorname{coss}(1-3.5)$ & 600 & 2.30 & 311.54 & 848.00 \\
\hline 4 & $\operatorname{oss}(1-3.5)$ & 1200 & -0.42 & 297.91 & 1084.00 \\
\hline 4 & $\operatorname{coss}(1-3.5)$ & 1200 & -2.42 & 298.41 & 1299.00 \\
\hline 4 & $\operatorname{Oss}(1-3.5)$ & 1200 & -15.43 & 304.97 & 1220.00 \\
\hline
\end{tabular}


Table 7. Thermal Conductivisy for the Paraffin Wax Specimene.

\begin{tabular}{|c|c|c|c|c|c|}
\hline $\begin{array}{l}\text { Lab } \\
\text { Code }\end{array}$ & $\begin{array}{l}\text { Specimen } \\
\text { Identifier }\end{array}$ & $\begin{array}{c}\text { Test } \\
\text { Duration } \\
\text { (s) }\end{array}$ & $\begin{array}{l}\text { Temp. } \\
\text { Rise } \\
\text { (K) }\end{array}$ & $\begin{array}{l}\text { Mean } \\
\text { Tomp. } \\
(\mathrm{K})\end{array}$ & $\begin{array}{l}\text { Thermal } \\
\text { Conductivity } \\
m \mathrm{~m} /(\mathrm{m} \cdot \mathrm{K})\end{array}$ \\
\hline 1 & $\operatorname{PWX}(1)$ & 600 & 7.50 & 295.00 & 245.00 \\
\hline 1 & PWX(1) & 600 & 4.50 & 295.00 & 242.00 \\
\hline 1 & PWX(1) & 600 & 2.70 & 295.00 & 239.00 \\
\hline 1 & PWX (1) & 600 & 7.80 & 295.00 & 251.00 \\
\hline 2 & PWX(3) & 564 & 1.00 & 298.39 & 201.00 \\
\hline 2 & $\operatorname{PWX}(3)$ & 564 & 3.43 & 299.94 & 194.00 \\
\hline 2 & PWX(3) & 564 & 6.69 & 302.77 & 190.00 \\
\hline 3 & PWX(4) & NR & 15.00 & 305.15 & 276.00 \\
\hline 3 & $\operatorname{PWX}(4)$ & NR & 15.00 & 306.15 & 291.00 \\
\hline 3 & PwX (4) & NR & 15.00 & 305.15 & 300.00 \\
\hline 3 & PWX (4) & MR & 15.00 & 305.15 & 281.00 \\
\hline 3 & PWX(4) & NR & 15.00 & 306.15 & 280.00 \\
\hline 3 & PWX(4) & NR & 15.00 & 307.15 & 292.00 \\
\hline 3 & PWX (4) & NR & 15.00 & 307.15 & 255.00 \\
\hline 3 & PWX (4) & NR & 15.00 & 307.15 & 264.00 \\
\hline 4 & PWX(1) & 600 & 4.56 & 310.14 & 296.00 \\
\hline 4 & $\operatorname{PWX}(1)$ & 600 & 4.56 & 309.80 & 292.00 \\
\hline 4 & PWX(1) & 600 & 0.60 & 299.35 & 242.00 \\
\hline 4 & PWX(1) & 600 & 4.90 & 310.50 & 261.00 \\
\hline 4 & PWX(1) & 600 & 0.50 & 300.20 & 214.00 \\
\hline 4 & $\operatorname{PWX}(1)$ & 600 & 0.40 & 299.75 & 336.00 \\
\hline 4 & PWX (1) & 600 & 3.90 & 309.40 & 373.00 \\
\hline 4 & PWX(1) & 600 & 5.40 & 313.65 & 300.00 \\
\hline 4 & $P W X(1)$ & 1200 & -8.80 & 305.65 & 324.00 \\
\hline 4 & PWX(1) & 1200 & -8.40 & 305.55 & 335.00 \\
\hline 4 & PWX (1) & 1200 & -1.00 & 298.95 & 223.00 \\
\hline 4 & PWX (1) & 1200 & -9.90 & 305.50 & 263.00 \\
\hline 4 & PWX (1) & 1200 & -1.30 & 299.60 & 152.00 \\
\hline 4 & PWX (1) & 1200 & -0.91 & 299.30 & 239.00 \\
\hline 4 & PWX(1) & 1200 & -8.00 & 304.85 & 340.00 \\
\hline 4 & PWX(1) & 1200 & -14.00 & 309.85 & 286.00 \\
\hline 5 & PWX (3) & NR & NR & 296.05 & 244.25 \\
\hline 5 & PWX (3) & NR & NR & 295.25 & 247.71 \\
\hline 5 & PWX(3) & NR & NR & 294.95 & 242.23 \\
\hline
\end{tabular}


Table 8. Mean Thermal Conductivity $\mathbf{k}$ and Percent Standard Deviation from the Mean for Each Type of Apparatus and Each Material.

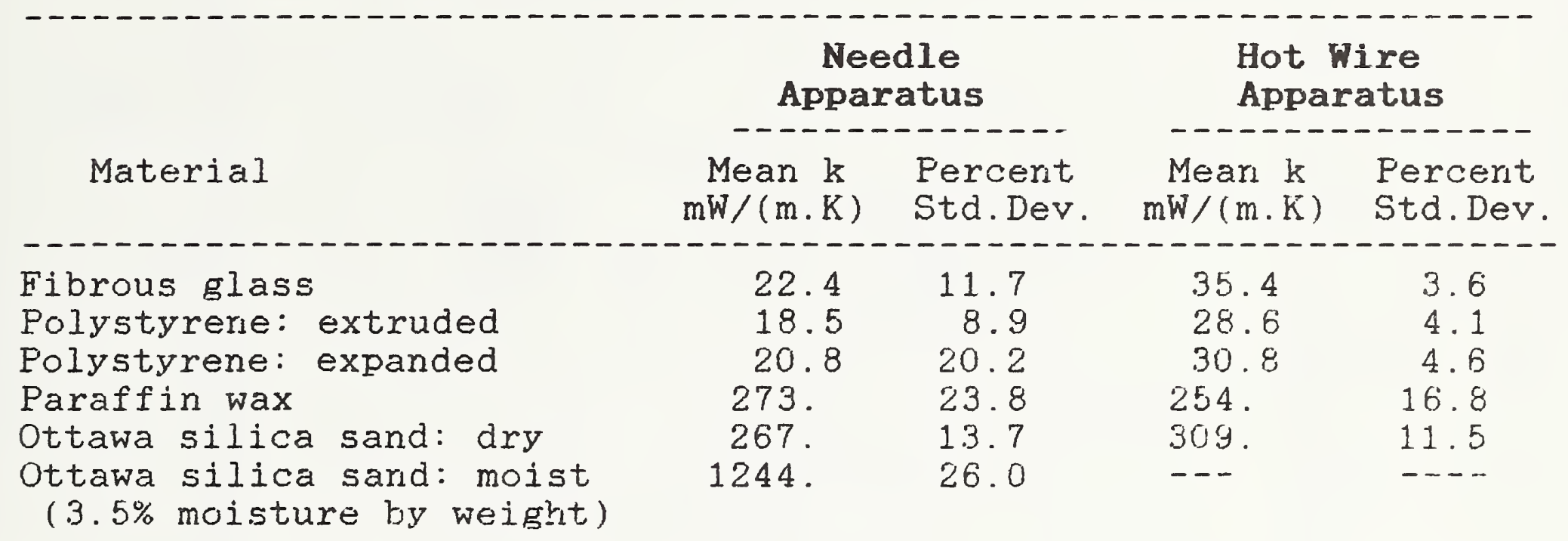




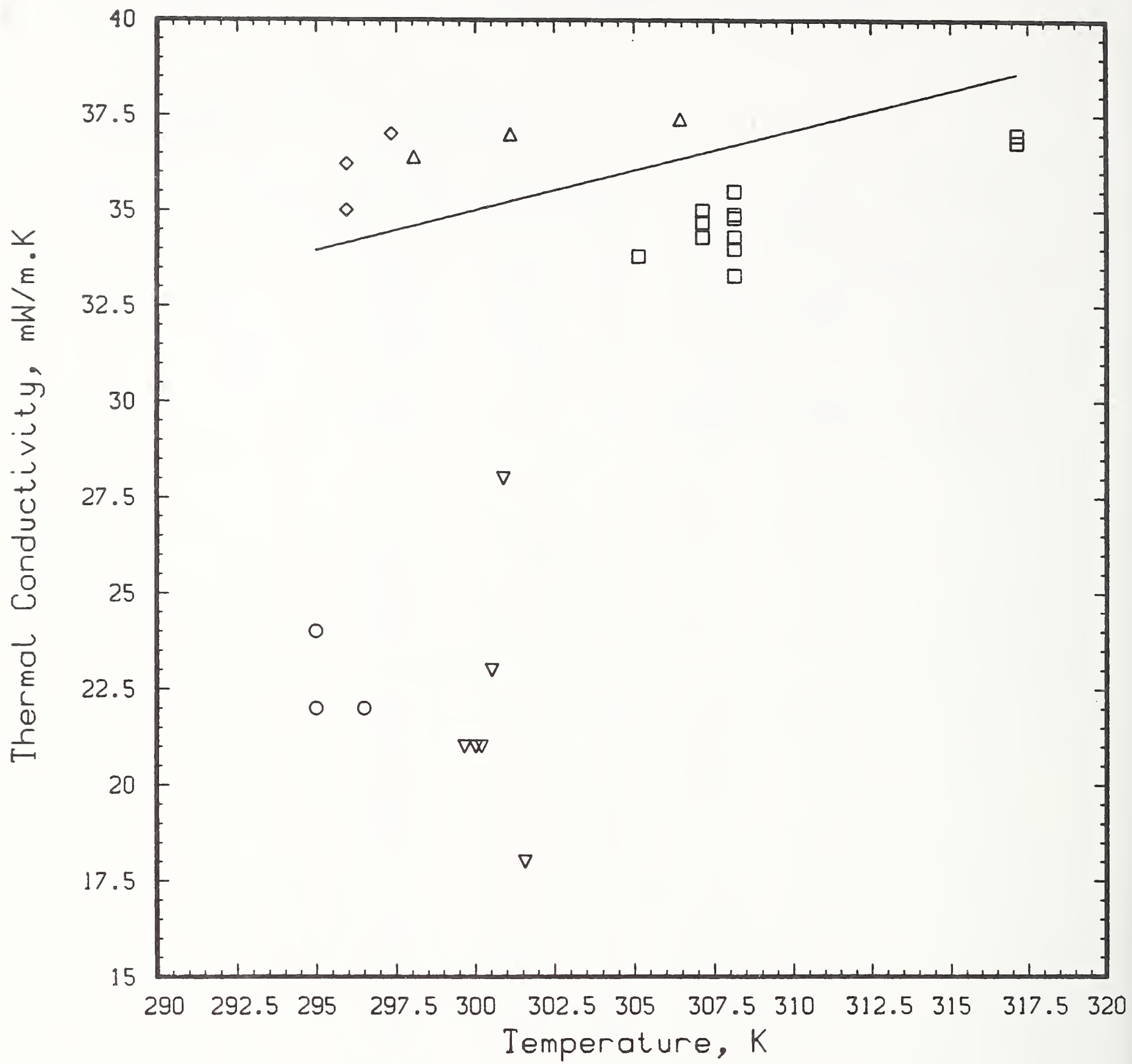

Figure 1. Interlaboratory comparison of thermal conductivity of fibrous glass insulation with a density of $45 \mathrm{~kg} / \mathrm{m}^{3}$. The solid line indicates the trend of data from the literature on similar material. 


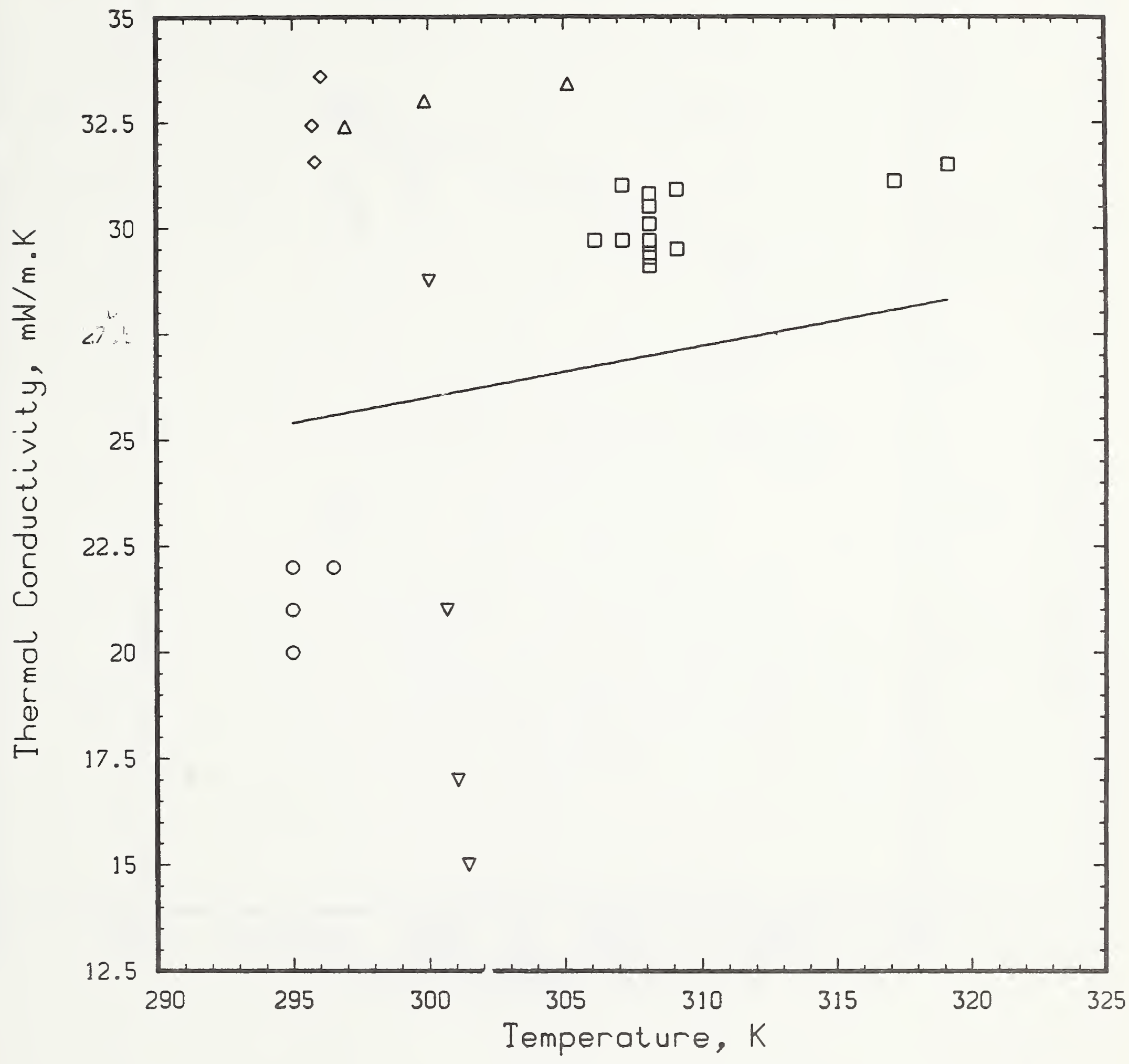

Figure 2. Interlaboratory comparison of thermal conductivity of expanded polystyrene insulation with a density of $21 \mathrm{~kg} / \mathrm{m}^{3}$. The solid line indicates the trend of data from the literature on similar material. 


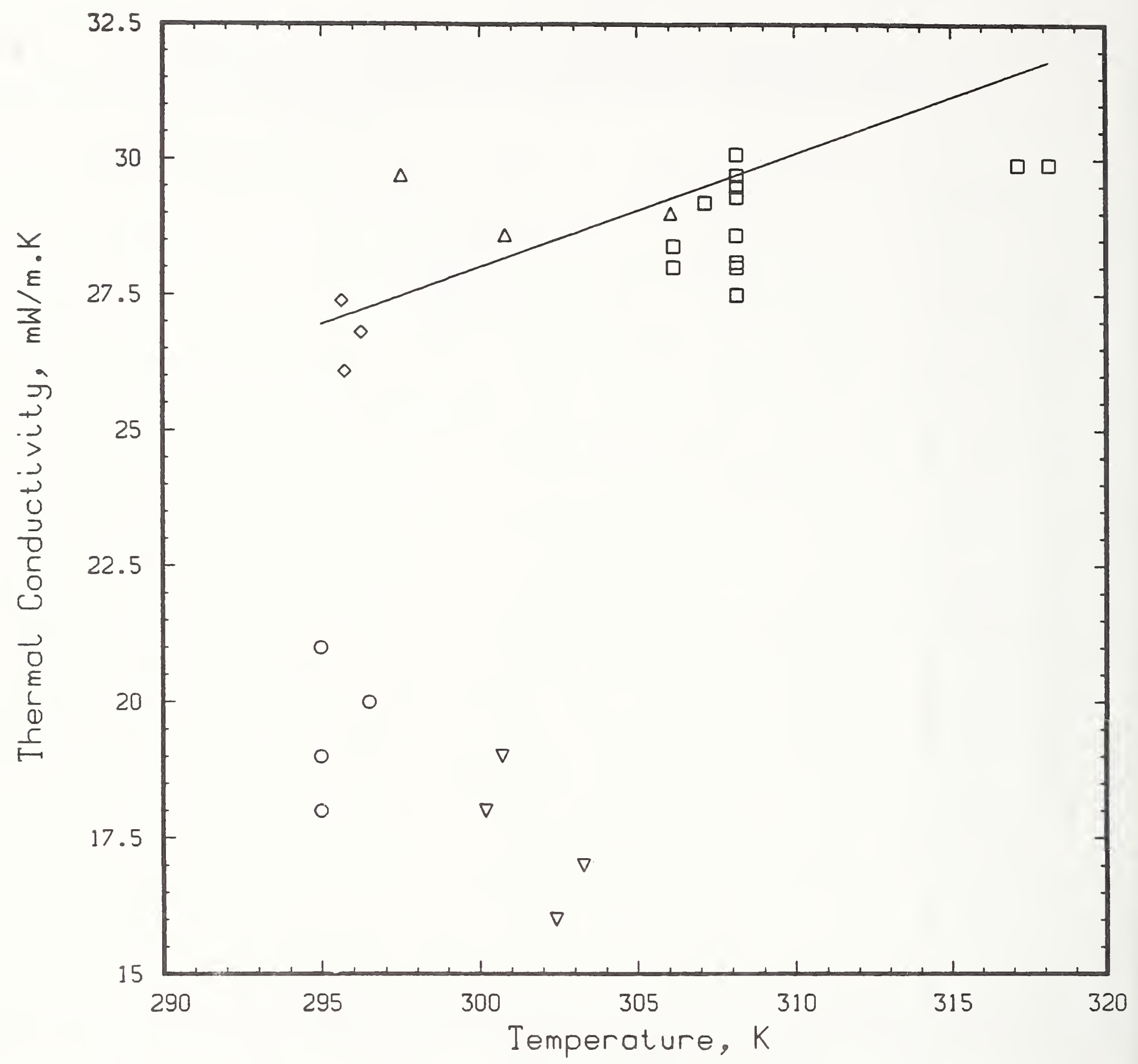

Figure 3. Interlabolatory comparison of thermal conductivity of extruded polystyrene insulation with a density of $32 \mathrm{~kg} / \mathrm{m}^{3}$. The solid line indicates the trend of data from the literature on similar material. 


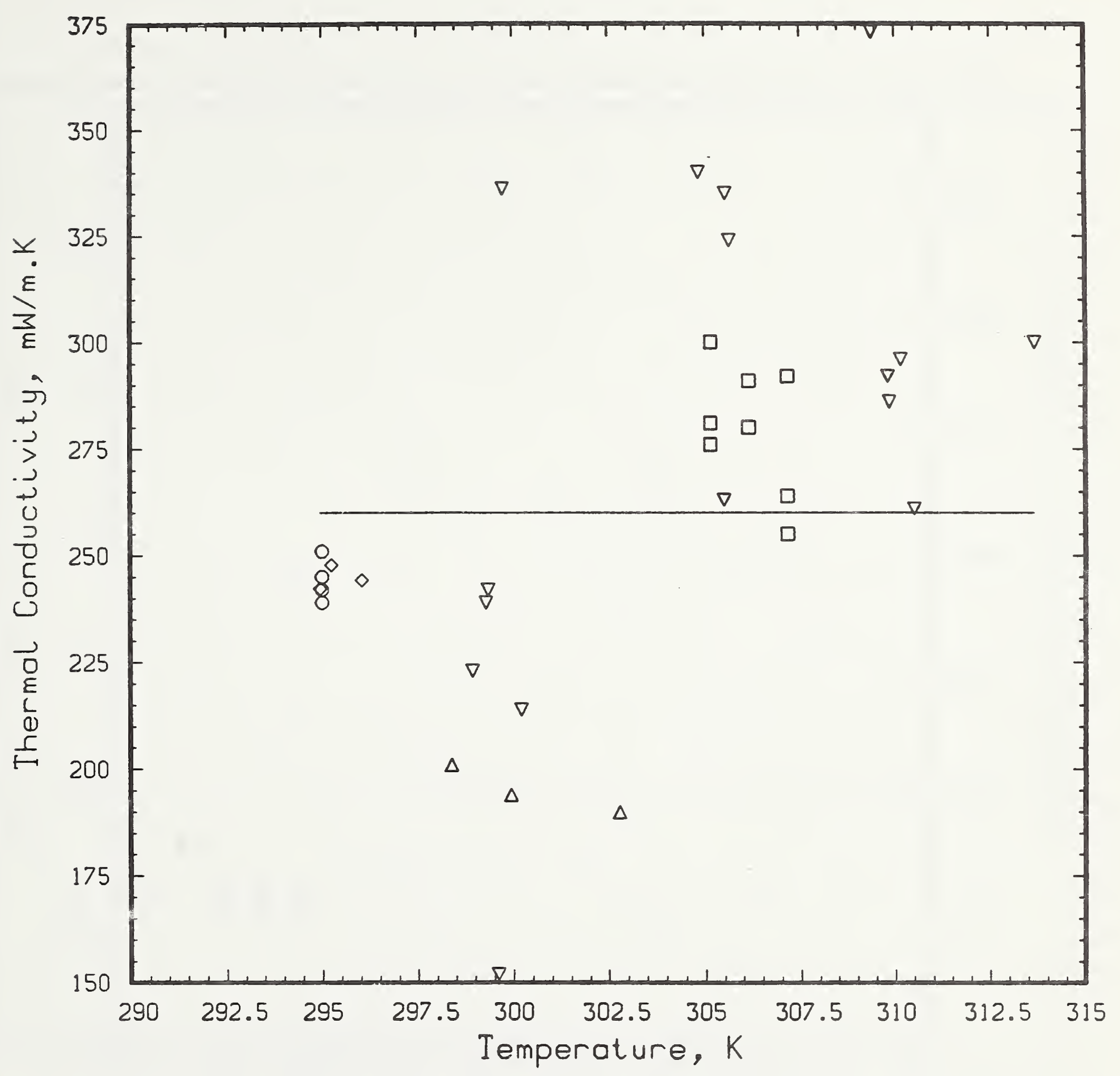

Figure 4. Interlaboratory comparison of thermal conductivity of paraffin wax with a density of $850 \mathrm{~kg} / \mathrm{m}^{3}$. The solid line indicates the trend of data from the literature on similar material. 


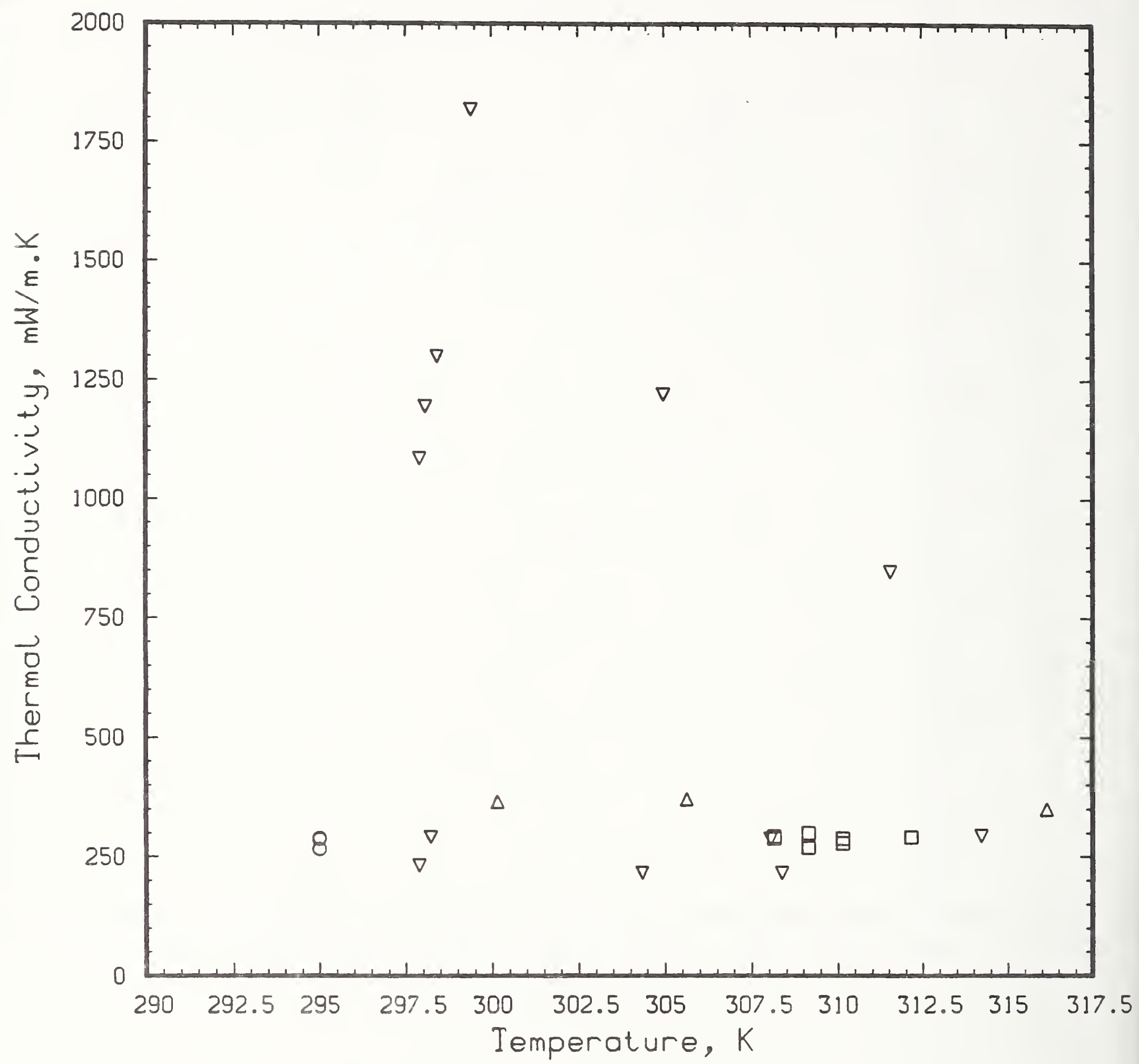

Figure 5. Interlaboratory comparison of thermal conductivity of Ottawa silica End with a density of $1640 \mathrm{~kg} / \mathrm{m}^{3}$. Downward-pointing triangles represent data for sand containing 3.5 percent by weight of moisture; all other symbols are for dry sand. 


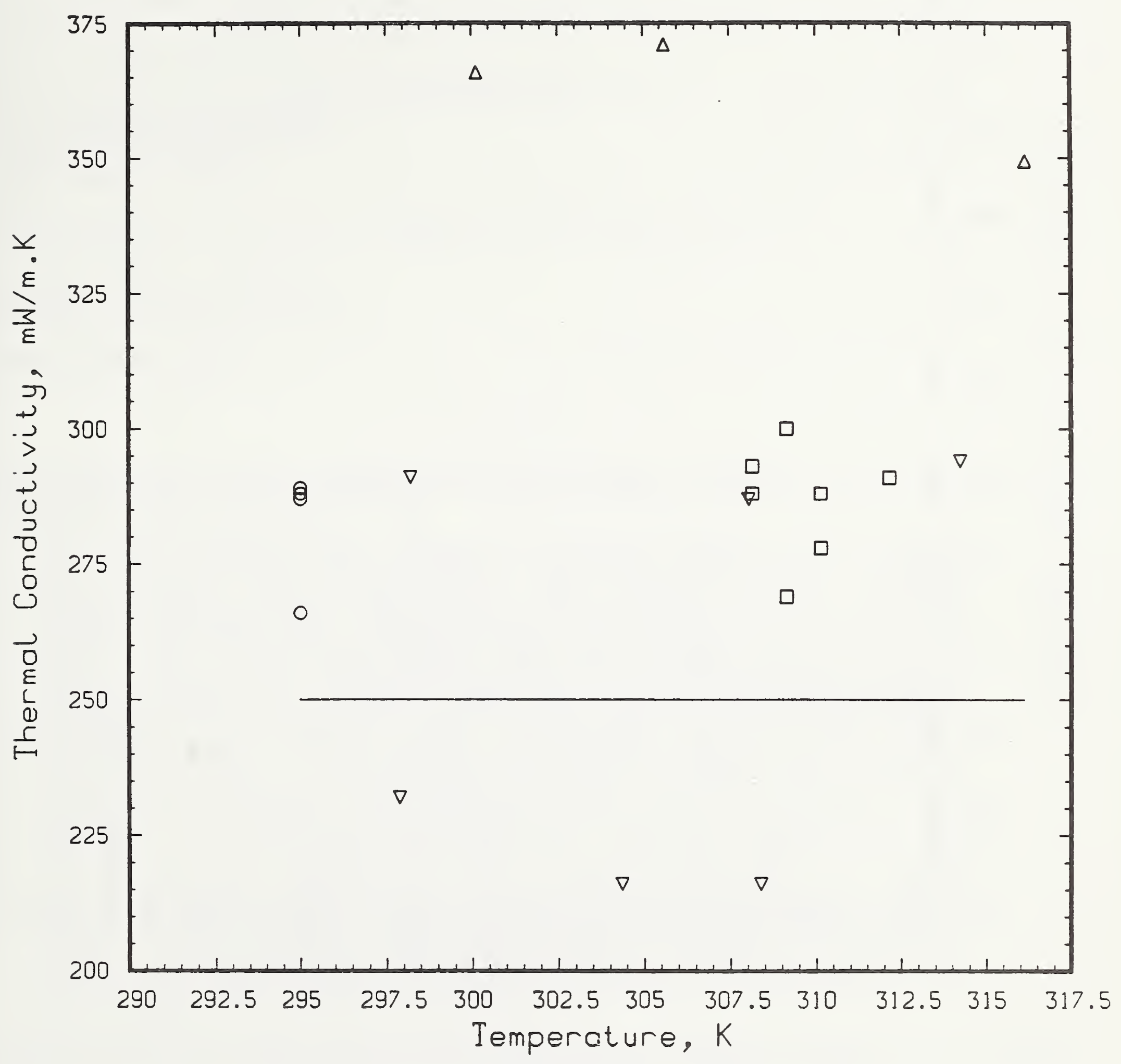

Figure 6. Interlaboratory compaxison of thermal conductivity of dry Ottawa silica sand with a density of $1640 \mathrm{~kg} / \mathrm{m}^{3}$. The solid line indicates the trend of data from the literature on similar material. 


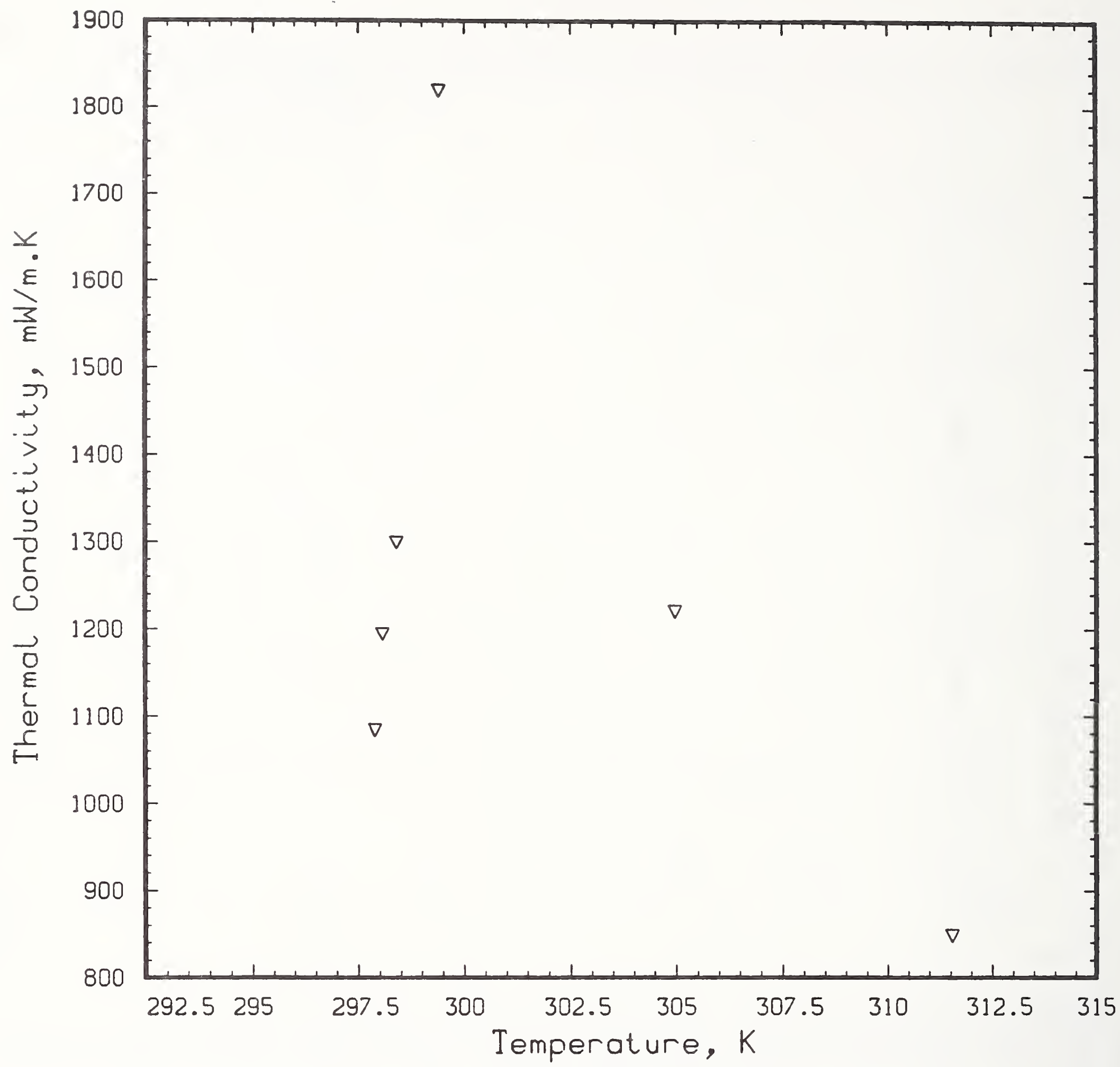

Figure 7. Interlaboratory comparison of thermal conductivity of Ottawa silica sand with a density of $1640 \mathrm{~kg} / \mathrm{m}^{3}$ and containing 3.5 percent by weight of moisture. 
4. TITLE AND SUBTITLE

Interlaboratory Comparison of Two Types of Line-Source Thermal-Conductivity Apparatus Measuring Five Insulating Materials

5. $\operatorname{AUTHOR}(\mathrm{S})$

Jerome G. Hust and David R. Smith

6. PERFORMING ORGANIZATION (If joint or other than NBS, see instructions) National Institute of Standards and Technology

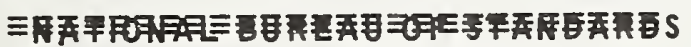

DEPARTMENT OF COMMERCE

WASHINGTON, D.C. 20234

9. SPONSORING ORGANIZATION NAME AND COMPLETE ADDRESS (Street, City, State, ZIP)

7. Contract/Grant No.

8. Type of Report \& Period Covered

IJ.S. Department of Energy

Oak Ridge National Laboratory

Oak Ridge, Tennessee 37830

10. SUPPLEMENTARY NOTES

Document describes a computer program; SF-185, FIPS Software Summary, is attached.

11. ABSTRACT (A 200-word or less factual summary of most significant information. If document includes a significant bliography or literature survey, mention it here)

We compare measurements of apparent thermal conductivity performed by five different laboratories. Subcommittee C-16.30. (Thermal Measurements) of the American Society for Testing and Materials (ASTM) sponsored this interlaboratory comparison. Two different types of line-source apparatus were used: the needle and the hoi wire. The five laboratories measured thermal conductivity of Ottawa silica sand, paraffin wax, and three insulating materials (fibrous glass, expanded polystyrene, and extruded polystyrene). Comparison of the test results illustrates the interlaboratory reproducibility. The standard deviation of the thermal conductivity results for the needle apparatus is 26 percent, whereas the standard deviation of the results for the hot-wire apparatus is 17 percent. For the insulating materials the mean values of the test results from the needle apparatus lie about 35 percent below those for the hot-wire apparatus. For the more dense materials, Ottawa sand and paraffin wax, the difference is about 15 percent. We do not at present know which apparatus is the more accurate. Further work needs to be done to establish and/or improve the reliability of each of these methods for use in a laboratory environment such as for quality control or research.

12. KEY WORDS (Six to twelve entries; alphabetical order; capitalize only proper names; and separate key words by semicolons) ambient temperature; apparent thermal conductivity: expanded polystyrene; extruded polystyrene; fibrous glass: hot wire; interlaboratory comparison: 1ine-source apparatus; needle probe; Ottawa silica sand; paraffin wax; thermal insulation

13. AVAILABILITY

$\mathrm{X}$ Unlimited

For Official Distribution. Do Not Release to NTIS

Order From Superintendent of Documents, U.S. Government Printing Office, Washington, D.C. 20402.

14. NO. OF

PRINTED PAGES

Order From National Technical Information Service (NTIS), Springfield, VA. 2216I

* U.S. GOVERNMENT PRINTING OFFICE: $1989-674-447 / 5027$ 




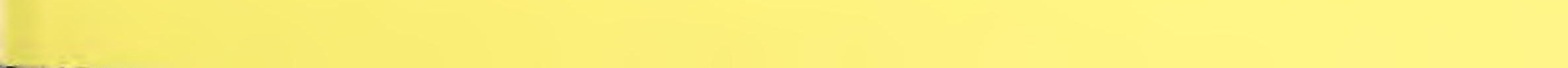


